\title{
PEMANFAATAN DAN PENGELOLAAN HAK ATAS KEKAYAAN INTELEKTUAL (HKI) SEBAGAI STRATEGI PENGEMBANGAN KEWIRAUSAHAAN
}

\author{
Muhammad Arif, Rosni \\ Jurusan Pendidikan Geografi Fakultas Ilmu Sosial Universitas Negeri Medan \\ Jl. Willem Iskandar Psr V Medan Estate Medan, 20211 Indonesia \\ Email: $\underline{\text { mhdarif@unimed.ac.id }}$
}

\begin{abstract}
Abstrak
Perguruan Tinggi (PT) dengan berbagai aspek yang berhubungan dengan kekayaan intelektual yang dimiliki oleh setiap dosennya merupakan aset yang bernilai ekonomis dan bermanfaat bagi pembangunan nasional dan daerah. Aset ini dapat dilihat berdasarkan hasil-hasil penelitian, temuan (invensi), rekayasa, dan pengabdian kepada masyarakat yang dilakukan para dosen. Penghargaan terhadap hasil-hasil tersebut haruslah diimplementasikan oleh dosen yang bersangkutan, bukan menunggu atau mengharapkan orang lain yang menghargainya. Berbagai isu tentang hak kekayaan intelektual menjadi tujuan utama dari tulisan ini. Hak atas Kekayaan Intelektual (HKI) atau Intelectual Property Rights (IPR) pada saat ini telah mendapat perlindungan dari pemerintah. Menghargai kekayaan intelektual diri sendiri berarti menghargai karya sendiri sekaligus menghindari konflik kepemilikan karya tersebut pada masa yang akan datang. Menghargai karya diri sendiri merupakan indikasi sikap mental wirausaha dari individu yang bersangkutan. Disamping itu, pemikiran ini juga sudah selayaknya menjadi perhatian, pemikiran dan dilaksanakan oleh seluruh insan perguruan tinggi, yang pada gilirannya akan meningkatkan kualitas perguruan tingginya dalam mengemban Tri Dharma PT. Oleh karena itu, pengelolaannya di PT yakni dengan membentuk Sentra KHI di Perguruan Tinggi.
\end{abstract}

Kata Kunci: Kekayaan intelektual untuk pengembangan kewirausahaan.

\section{PENDAHULUAN}

Konsep Hak atas Kekayaan Intelektual (HKI) pada dasarnya telah disosialisasikan melalui program pengembangan budaya kewirausahaan yang dilakukan oleh Ditbinlitabmas Dirjen Dikti sejak tahun 1999. HKI adalah hak yang timbul bagi hasil olah pikir otak yang menghasilkan suatu produk atau proses yang berguna untuk manusia (Dirjen HKI, 2001). HKI merupakan hak untuk menikmati secara ekonomis hasil suatu kreativitas intelektual, sebagai karya yang timbul atau lahir karena kemampuan intelektual manusia. Kekayaan intelektual seorang penemu berarti merupakan kekayaan yang timbul dari kemampuan intelektualnya yang hasilnya dalam bentuk karya dibidang teknologi, ilmu pengetahuan, seni dan sastra. Karya itu dihasilkan atas kemampuan intelektual melalui pemikiran, daya cipta dan rasa yang memerlukan curahan tenaga, waktu, dan biaya untuk memperoleh "produk" dengan landasan kegiatan penelitian ataupun pengabdian kepada masyarakat.

Dalam era globalisasi upaya perlindungan terhadap HKI begitu mencuat dan menjadi perhatian bagi banyak kalangan, tidak hanya bagi pengatur kebijakan pemerintah, pebisnis dan investor, tetapi juga oleh para pakar. Aspek HKI telah dimasukkan ke dalam skenario General Agreements on Trade and Tarrifs (GATT) dan World Trade Organization (WTO) melalui deklarasi atau perjanjiian Trade-Related aspects on Intellectual Property Rights (TRIPs), sehingga kekayaan intelektual sudah 


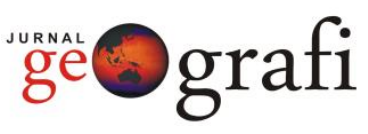

merupakan sarana perdagangan untuk memenangkan kompetisi pada ekonomi global, dengan tujuan komersial yang legal. Konvensi internasional yang lain, yang juga telah diratifikasi pemerintah Indonesia yang berkaitan dengan HKI yaitu World Intellectual Property Organization (WIPO) dan Convention of Biological Biodiversity (CBD). Ratifikasi terhadap perjanjian-perjanjian tersebut telah dilakukan sejak Januari 1995, dan sejak Januari 2000 pemerintah sudah memperhatikan secara sungguh-sungguh aspek HKI dalam strategi penelitian, pengabdian, industri, dan perdagangan.

Keseriusan pemerintah untuk melindungi aspek-aspek yang berhubungan dengan HKI dapat dilihat dengan telah diberlakukannya UU No. 31/2000 tentang Desain Industri, UU No. 32/2000 tentang Desain Tata Letak Sirkuit Terpadu, UU No. 14/2001 tentang Paten, UU No. 15/2001 tentang Merek, dan UU No. 19/2002 tentang Hak Cipta. Pertanyaan yang muncul dalam hubungan ini adalah apakah hasil karya seni dan desain, penelitian, industri, penerapan teknologi, dan perdagangan yang telah kita lakukan sudah dihargai dan didaftarkan ke institusi yang berwenang untuk melindunginya?

\section{Pemanfaatan dan Pengelolaan HKI}

Mencermati perkembangan teknologi digital yang demikian pesat, maka pada saatnya akan muncul dan/atau dapat saja ditemukan permasalahan terhadap hak atas kekayaan intelektual, khususnya mengenai masalah hasil ciptaannya. Sebab salah satu aspek pada teknologi tersebut apabila "diambil" oleh pihak lain, lalu didaftarkannya ke Kementerian Hukum dan Hak Asasi Manusia (HAM) maka pihak lain itulah yang memiliki hak cipta terhadap aspek tersebut. Hanya persoalan kalah cepat saja dapat mengakibatkan permasalahan hak cipta, dan menimbulkan tuntutan kriminal ataupun kejahatan pidana. Kasus pembajakan melalui penggandaan suatu produk dengan harga jual yang relatif murah, juga merupakan masalah dalam bidang hak cipta ataupun masalah penanggulangan praktek permainan curang. Keadaan ini merupakan contoh yang relatif sederhana pada aspek yang berhubungan dengan HKI.

Bagaimana aspek HKI di Perguruan Tinggi (PT)?. Melalui tri darmanya maka setiap PT haruslah memperhatikan aspek HKI pada penelitian atau temuan dan pengabdian yang dilakukan dosennya. Hasil-hasil penelitian yang dilaksanakan PT selama ini masih berorintasi kepada karya ilmiah yang dipublikasikan di majalah ilmiah dalam rangka memperoleh angka kredit sebagai kinerja untuk kenaikan pangkat/golongan. Hasil penelitian yang bernilai komersial dan memiliki kelayakan HKI masih kurang mendapat (menjadi) perhatian, misalnya penelitian tentang: bahan pengawet wajah agar tetap tegang/kencang, obat untuk tetap perkasa seperti seekor kuda, makanan yang merangsang agar mata tidak mudah lelah dan mengantuk, makanan yang merangsang mata untuk dapat menembus pandangan walau terhadang tembok, makanan atau obat yang membuat manusia mampu menyelam seperti seekor ikan pari di laut, makanan yang membuat rambut tetap tumbuh subur sehingga terhindar dari kebotakan kepala, sepatu yang tahan/awet dan tidak mudah dilekati abu/kotoran, dan lain-lain. Kurangnya perhatian para peneliti untuk menemukan aspek-aspek yang komersial tersebut, kemungkinan karena belum dipahaminya manfaat HKI itu, dan ada pula yang tidak setuju apabila hasil penelitiannya atau temuannya untuk dilindungi dalam bentuk paten, karena karyanya itu hanya sebagai amal baktinya saja dengan harapan akan mendapat imbalan dari Yang Maha Kuasa.

Rendahnya pemahaman dan pengetahuan mengenai manfaat dan pengelolaan HKI di negara kita, padahal dalam era globalisasi menuntut pelaku bisnis domestik agar dapat mengikuti standar perdagangan global, termasuk 
masallah HKI, sehingga sangat diperlukan suatu jasa pengelolaan dan implementasi terhadap HKI. Disisi lain, meningkatnya kebutuhan industri di Indonesia atas alternatif pengadaaan teknologi dan inovatif yang dapat mendorong keunggulan kompetitif baik di tingkat lokal ataupun global. Sehingga diperlukan suatu jasa yang memberikan alternatif pengadaan lisensi teknologi dan inovasi khususnya yang telah dilindungi. Terhadap kedua analisa tersebut bila kita mau menyadarinya, bahwa aspek-aspek HKI itu pada hakikatnya merupakan peluang bisnis.

Sehubungan dengan adanya perlindungan terhadap HKI maka setiap karya yang kita hasilkan sudah saatnya agar diberi perlindungan. Kemudian, sudah saatnya pula setiap peneliti atau dosen di perguruan tinggi, yang melakukan penelitian, didorong untuk menjadi peneliti penemu (inventor), agar dapat menghasilkan paten atau hak cipta yang menjadi salah satu sumbangan nyata bagi kemajuan teknologi, sekaligus sebagai prasarana peningkatan kredibilitas perguruan tingginya di masyarakat.

Usaha yang dapat dilakukan oleh perguruan tinggi sehubungan dengan pemanfaatan aset kekayaan intelektual dan pengelolaannya adalah dengan membentuk Sentra KHI di Perguruan Tinggi. Sentra ini merupakan suatu unit organisasi yang menangani HKI dari suatu kelompok inventor pada suatu lembaga induk. Pada PT lembaga induk yang dimaksud adalah Universitas atau Institut. Sentra HKI akan mengelola karya intelektual ataupun sebagai konsultan dalam pengurusan administrasi bagi perlindungan terhadap berbagai aspek HKI dimaksud. Secara umum ruang lingkup tugas dan fungsi sentra HKI ini meliputi ke dalam dan ke luar organisasi, yang sekaligus melaksanakan fungsi manajemen, teknologi, hukum, dan pemasaran terhadap aspek yang berhubungan dengan HKI. Beberapa sentra HKI yang telah terbentuk di beberapa PT di Indonesia, misalnya ITB dengan nama "Kantor Manajemen HaKI", di IPB dan UGM dengan nama "Gugus $\mathrm{HKI}$, di UNSRI dengan nama "Sentra HaKI" dan di ANDALAS dengan nama "Komisi HaKI".

\section{Aspek HKI yang Dilindungi}

Secara garis besar HKI dibagi dalam 2 (dua) bagian yaitu hak cipta (copyrights) dan hak kekayaan industri yang mencakup paten, desain industri, merek, penanggulangan praktek persaingan curang, desain tata letak sirkuti terpadu, dan rahasia dagang (Dirjen HKI, 2001). Ciptaan adalah hasil setiap karya pencipta dalam bentuk yang khas dan menunjukkan keasliannya dalam lapangan ilmu pengetahuan, seni, dan sastra. Berdasarkan buku panduan hak kekayaan intelektual yang diterbitkan oleh Dirjen HKI, Kementerian Hukum dan HAM aspek-aspek kekayaan intelektual tersebut berikut ini diuraikan satu persatu.

Hak Cipta adalah hak khusus bagi pencipta. Apabila suatu ciptaan terdiri dari beberapa bagian (tersendiri) yang diciptakan dua orang atau lebih maka yang dianggap sebagai penciptanya adalah orang yang memimpin serta mengawasi penyelesaian seluruh ciptaan itu. Ciptaan yang dibuat dalam hubungan dinas dengan pihak lain dalam lingkungan pekerjaannya, maka pihak yang mengerjakannya adalah sebagai pemegang hak cipta, kecuali ada perjanjian lain antara kedua belah pihak. Ciptaan yang dibuat dalam hubungan kerja atau berdasarkan pesanan, maka pihak yang membuat karya cipta itu dianggap sebagai pencipta dan pemegang hak cipta. Apabila suatu badan hukum mengumumkan bahwa suatu ciptaan berasal dari padanya dengan tidak menyebut seseorang sebagai penciptanya, kecuali jika dapat dibuktikan sebaliknya. 


\section{iogratif}

Lamanya hak perlindungan terhadap suatu ciptaan berbeda-beda antara lain :

- Ciptaan buku, ceramah, alat peraga, lagu, drama, tari, seni rupa, peta, arsitektur, seni batik, terjemahan, tafsir, dan saduran, berlaku selama hidup pencipta ditambah 50 tahun setelah pencipta meninggal dunia.

- Ciptaan program komputer, senimatografi, rekaman suara, karya pertunjukan, karya siaran, berlaku selama 50 tahun sejak pertama kali diumumkan.

- Ciptaan atas fotografi, berlaku selama 25 tahun sejak pertama kali diumumkan dan ciptaan atas karya susunan perwajahan karya tulis yang diterbitkan, berlaku selama 25 tahun sejak pertama kali diterbitkan.

- Ciptaan yang dimiliki atau dipegang oleh badan hukum, berlaku selama 50 tahun sejak pertama kali diumumkan.

- Untuk hak cipta yang berupa fotografi dan susunan perwajahan karya tulis yang diterbitkan dan dipegang oleh suatu badan hukum, berlaku selama 25 tahun.

- Ciptaan yang dipegang atau dilaksanakan oleh negara, berlaku tanpa batas.

Paten adalah hak eksklusif yang diberikan oleh negara kepada inventor atas hasil invensinya dibidang teknologi. Inventor itu adalah seseorang yang secara sendiri atau beberapa orang yang secara bersama-sama melaksanakan ide yang dituangkan kedalam kegiatan yang menghasilkan invensi. Paten dapat dibagi dua yakni paten dan paten sederhana. Perbedaan antara paten dengan paten sederhana terletak pada jumlah klaim, masa perlindungannya, pengumuman permohonan patennya, jangka waktu pengajuan keberatan, substansi pemeriksaan, dan lamanya pemeriksaan substansi. Perlindungan terhadap hak paten adalah 20 tahun sedangkan paten sederhana selama 10 tahun dan terhitung sejak tanggal penerimaan permohonan paten tersebut. Dalam hal ini yang dimaksud dengan klaim adalah bagian dari permohonan yang menggambarkan inti invensi yang dimintakan perlindungan hukumnya, yang harus diuraikan secara jelas dan harus didukung oleh deskripsi. Klaim tersebut mengungkapkan tentang semua keistimewaan teknik yang terdapat dalam invensi. Dalam penulisan klaim hal-hal yang perlu diperhatikan adalah: (a) Klaim tidak boleh berisi gambar atau grafik tetapi dapat berisi tabel, rumus matematika ataupun rumus kimia, dan (b) Klaim tidak boleh berisi kata-kata yang sifatnya meragukan. Kemudian, perlindungan terhadap hak paten hanya diberikan untuk penemuan yang baru, mengandung langkah-langkah inventif, dan dapat diterapkan pada industri.

Desain Industri adalah suatu kreasi tentang bentuk, konfigurasi, atau komposisi garis atau warna, atau garis dan warna, atau gabungan dari padanya yang berbentuk tiga dimensi atau dua dimensi yang memberikan kesan estetis dan dapat diwujudkan dalam pola tiga dimensi atau dua dimensi serta dapat dipakai untuk menghasilkan suatu produk, barang, komoditas industri, atau kerajinan tangan. Hak desain industri adalah hak eksklusif yang diberikan negara kepada pendesain atas hasil kreasinya untuk selama waktu tertentu melaksanakan sendiri, atau memberikan persetujuannya kepada pihak lain untuk melaksanakan hak tersebut.

Perlindungan terhadap hak desain industri diberikan untuk jangka waktu 10 tahun terhitung sejak tanggal penerimaannya. Adapun lingkup desain industri yang mendapat perlindungan adalah desain industri yang baru dan tidak bertentangan dengan peraturan perundang-undangan yang berlaku, ketertiban umum, agama atau kesusilaan.

Merek adalah suatu "tanda" yang berupa gambar, nama, kata, huruf-huruf, angka-angka, susunan warna atau kombinasi unsur-unsur tersebut yang 
memiliki daya pembeda dan digunakan dalam kegiatan perdagangan barang dan jasa. Merek dapat dibedakan atas 3 (tiga) jenis antara lain: Merek Dagang adalah merek yang digunakan pada barang yang diperdagangkan oleh seseorang atau beberapa orang secara bersama-sama atau badan hukum untuk membedakan dengan barang-barang sejenis lainnya. Merek Jasa adalah merek yang digunakan pada jasa yang diperdagangkan oleh seseorang atau beberapa orang secara bersama-bersama atau badan hukum untuk membedakan dengan jasa-jasa sejenis lainnya. Merek Kolektif adalah merek yang digunakan pada barang dan/atau jasa dengan karakteristik yang sama dengan yang diperdagangkan oleh beberapa orang atau badan hukum secara bersama-sama untuk membedakan dengan barang dan/atau jasa sejenis lainnya.

Jangka waktu perlindungan hukum terhadap suatu merek adalah 10 tahun dan berlaku surut sejak tanggal penerimaan permohonan merek yang bersangkutan, dan dapat diperpanjang setiap kali untuk jangka waktu yang sama.

Desain Tata Letak Sirkuit Terpadu (DTLST) terdiri dari dua konsep dalam hal ini yakni Sirkuit Terpadu dan Desain Tata Letak. Sirkuit Terpadu adalah suatu produk dalam bentuk jadi atau setengah jadi, yang didalamnya terdapat berbagai elemen dan sekurang-kurangnya satu dari elemen tersebut adalah elemen aktif, yang sebagian atau seluruhnya saling berkaitan serta dibentuk secara terpadu di dalam sebuah bahan semikonduktor yang dimaksudkan untuk menghasilkan fungsi elektronik. Desain Tata Letak adalah kreasi berupa rancangan peletakan tiga dimensi dari berbagai elemen, sekurangkurangnya satu dari elemen tersebut adalah elemen aktif, serta sebagian atau semuanya interkoneksi dalam suatu sirkuit terpadu dan peletakan tiga dimensi tersebut dimaksudkan untuk persiapan untuk pembuatan sirkuit terpadu.
Hak Desain Tata Letak Sirkum Terpadu (DTLST) merupakan hak eksklusif yang diberikan oleh negara kepada pendesain atas hasil kreasinya. DTLST yang mendapat perlindungan adalah desain yang orisinil, bukan merupakan sesuatu yang umum bagi para pendesain, dan tidak bertentangan dengan peraturan perundang-undangan yang berlaku, ketertiban umum, agama atau kesusilaan. Perlindungan terhadap hak DTLST selama 10 tahun yang terhitung sejak tanggal penerimaannya.

Rahasi Dagang adalah informasi yang tidak diketahui oleh umum dibidang teknologi dan/atau bisnis, yang mempunyai nilai ekonomi karena berguna dalam kegiatan usaha, dan dijaga kerahasiaannya oleh pemilik rahasia dagang. Lingkup perlindungan rahasia dagang meliputi metode produksi, metode pengolahan, metode penjualan, atau informasi lain dibidang teknologi dan/atau bisnis yang memiliki nilai ekonomi dan tidak diketahui oleh masyarakat umum.

Hak-hak yang dimiliki oleh pemegang/pemilik hak rahasia dagang antara lain hak untuk: (a) Menggunakan sendiri rahasia dagang yang dimilikinya, (b) Memberikan lisensi kepada rahasia dagang atau melarang pihak lain untuk menggunakan rahasia dagang atau mengungkapkan rahasia dagang itu kepada pihak ketiga untuk kepentingan yang bersifat komersial, dan (c) Mengajukan gugatan secara perdata dan/atau tuntutan secara pidana kepada siapapun yang dengan sengaja dan tanpa hak melakukan perbuatan sebagaimana disebutkan pada butir b diatas. Sedangkan untuk mendapatkan hak perlindungan rahasia dagang tidak perlu diajukan pendaftaran atau permohonan, karena UU secara langsung akan melindungi rahasia dagang tersebut. Apabila informasi tersebut bersifat rahasia, mempunyai nilai ekonomi, dan dijaga kerahasiaannya melalui upaya sebagaimana mestinya, yang memuat ukuran kewajaran, 


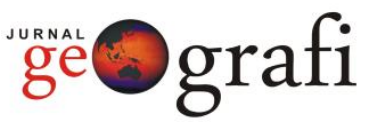

kelayakan, dan kepatuhan yang harus dilakukan.

Berdasarkan penjelasan terhadap ke enam bentuk HKI, dimana seseorang, kelompok atau badan hukum akan mendapatkan hak eksklusif dari negara, baik sebagai penemu, pendesain, pencipta dan sebagainya, maka upaya yang berhubungan dengan penanggulangan praktek persaingan curang juga dapat dilaksanakan. Setiap pelanggaran yang terjadi terhadap keenam bentuk HKI, maka pemegang/pemilik hak tersebut dapat mengajukan gugatan secara perdata dan/atu tuntutan secara pidana. Demikian pula terhadap masalah penanggulangan praktek persaingan curang, seseorang yang merasa dirugikan akibat dari perbuatan orang lain, maka masalah dapat ini dapat diajukaan ke meja pengadilan.

\section{Manfaat HKI Terhadap Bidang Ekonomi}

Terhadap kekayaan intelektual yang dimiliki oleh dosen di Perguruan Tinggi (PT), bahwa sejak 1999/2000 Ditbinlitabmas Dirjen Dikti telah melakukan antisipasinya dengan melakukan analisis potensi Hak atas Kekayaan Intelektual (HKI) terhadap hasil kegiatan penelitian dan pengabdian kepada masyarakat dari staf pengajar PT. Analisis potensi tersebut kemudian ditindaklanjuti secara sistematis melalui program Unggulan Berpotensi Hak atas Kekayaan Intelektual (UBER HKI), yang perolehannya dikompetisikan secara nasional oleh semua staf pengajar PT yang pernah atau sedang melakukan penelitian dan pengabdian kepada masyarakat. UBER HKI pada dasarnya masuk kedalam lingkup upaya pengembangan budaya kewirausahaan.

Hasil-hasil kegiatan penelitian dan pengabdian kepada masyarakat PT pada hakikatnya memiliki nilai temuan yang potensial untuk dapat "dijual", yang pada gilirannya berdampak positif terhadap pelaksana atau penemunya (dosen) ataupun bagi universitas yang bersangkutan.
Secara internasional badan yang membidangi HKI adalah World Intelectual Property Organization(WIPO), suatu badan khusus Perserikatan Bangsa-Bangsa (PBB), dan Indonesia termasuk sebagai salah satu anggotanya. Oleh karenanya aspekaspek yang berhubungan dengan HKI sudah jelas memiliki "nilai jual" atau dapat diperdagangkan secara gobal. Pada saat ini dan pada masa yang akan datang permasalahan HKI tidak dapat dilepaskan dari dunia perdagangan dan investasi. Aspek-aspek yang berhubungan dengan HKI sangat penting dalam pembangunan ekonomi dan perdagangan pada suatu negara, dan bagi negara-negara anggota WIPO.

Hak eksklusif yang diberikan oleh negara kepada individu pelaku HKI (inventor, pencipta, pendesain dan sebagainya) adalah dimaksudkan untuk pemberian penghargaan atas hasil karya (kreativitas) nya dan agar orang lain terangsang untuk lebih lanjut mengembangkannya lagi. Sehingga dengan sistem HKI tersebut kepentingan masyarakat diitentukan melalui mekanisme pasar. HKI yang masuk ke pasar lokal ataupun internasional akan memberikan kontribusi ekonomi bagi pelakunya, dan pada gilirannya juga kepada bangsa dan negaranya.

\section{PENUTUP}

Pemberian hak eksklusif oleh negara kepada pelaku HKI merupakan penghargaan terhadap hasil karya atau kreativitasnya. Sehingga setiap aspek yang berhubungan dengan HKI telah mendapat perlindungan dari pemerintah.

HKI merupakan isu yang sangat penting dan mendapat perhatian, baik dalam forum nasional maupun internasional. Dengan dimasukkannya TRIPs dalam paket WTO merupakan indikasi bahwa telah dimulainya era baru terhadap perkembangan HKI diseluruh dunia. Dalam era saat ini, negara berkembang dan negara maju telah samasama dalam memanfaatkan HKI, namun harus diakui bahwa negara maju lebih 
mampu dalam mengelola aset HKI menjadi produk yang menghasilkan uang, sedangkan negara berkembang relatif kurang mampu karena kurang dipahaminya manfaat dan pengelolaan HKI.

Masalah yang penting bagi negara Indonesia dalam memasuki era kompetisi perdagangan global adalah kurangnya pemahaman para pelaku yang terkait dengan HKI, seperti peneliti, industriawan, pebisnis, desainer dan sebagainya dalam mengadopsi dan memanfaatkan sistem HKI dalam rangka meningkatkan daya kompetisinya.

Hasil kegiatan penelitian dan pengabdian kepada masyarakat yang bernilai komersial dan memiliki kelayakan HKI harus sudah menjadi perhatian dan diminati oleh staf pengajar PT. Melalui hasil-hasil tersebut pada gilirannya akan memberikan manfaat ekonomi, tidak hanya bagi diri sendiri pelakunya tetapi juga bagi universitasnya. Universitas yang ada di Indonesia sudah seharusnya memiliki "Sentra HKI" yang merupakan sarana berkumpulnya para inventor atau peneliti dalam memanfaatkan dan mengelola aset intelektual.

\section{DAFTAR PUSTAKA}

Ditbinlitabmas, Dirjen Dikti. (2000). Panduan Usulan UBER-HaKI.Jakarta: Ditbinlitabmas, Dirjen Dikti Departemen Pendidikan Nasional.

Dirjen Hak Kekayaan Intelektual. (2000). Undang-undang No. 31 Tahun 2000 tentang Desain Industri. Jakarta: Direktorat Jenderal Hak Kekayaan Intelektual, Departemen Kehakiman dan Hak Asasi Manusia Republik Indonesia.

Dirjen Hak Kekayaan Intelektual. (2000). Undang-undang No. 32 Tahun 2000 tentang Desain Tata Letak Sirkuit Terpadu. Jakarta: Direktorat Jenderal Hak Kekayaan Intelektual, Departemen Kehakiman dan Hak Asasi Manusia Republik Indonesia.
Dirjen Hak Kekayaan Intelektual. (2001). Undang-undang No. 14 Tahun 2001 tentang Paten. Jakarta: Direktorat Jenderal Hak Kekayaan Intelektual, Departemen Kehakiman dan Hak Asasi Manusia Republik Indonesia.

Dirjen Hak Kekayaan Intelektual. (2001). Undang-Undang No. 15 Tahun 2001 tentang Merek. Jakarta: Direktorat Jenderal Hak Kekayaan Intelektual, Departemen Kehakiman dan Hak Asasi Manusia Republik Indonesia.

Dirjen Hak Kekayaan Intelektual. (2001). Buku Panduan (Pertanyaan dan Jawaban) Hak Kekayaan Intelektual. Jakarta: Direktorat Jenderal Hak Kekayaan Intelektual, Departemen Kehakiman dan Hak Asasi Manusia Republik Indonesia.

Dirjen Hak Kekayaan Intelektual. (2002). Undang-undang No. 19 Tahun 2002 tentang Hak Cipta. Jakarta: Direktorat Jenderal Hak Kekayaan Intelektual, Departemen Kehakiman dan Hak Asasi Manusia Republik Indonesia. 